\title{
Concepto impeditur tam uicio uiri quam mulieris - kobieca i męska niepłodność na podstawie traktatu Liber de sinthomatibus mulierum
}

Concepto impeditur tam uicio uiri quam mulieris the female and male infertility in the treatise Liber de sinthomatibus mulierum

\section{Summary}

This article based on the treatise Liber de sinthomatibus muluerum considered one of the most important medieval treaties on gynecology and obstetrics discusses the issues related to the problem of male and female infertility. Despite the fact that its author remains unknown the treatise is an important source showing the state of medical knowledge in this area. Despite the fact that the author tells about procreation of both sexes, he definitely paid more attention to women what indicates that for him they were more responsible for the lack of offspring. Information about irregular menstruation, abnormal physical structure and psychological problems show that it was already known how many factors impact on procreation.

Słowa kluczowe: wieki średnie, Lier de sinthomatibus mulierum, bezpłodność

Keywords: Middle Ages, Lier de sinthomatibus mulierum, infertility 
Od wieków wszelkimi kwestiami związanymi z ciążą, porodem, opieką nad matką i noworodkiem zajmowały się głównie kobiety, ponieważ to one wiedziały, czego doświadczają i potrzebują, wydając na świat potomstwo. Już w starożytności w małżeństwach bezdzietnych o niepłodność posądzano zazwyczaj kobiety, nawet jeśli wiedziano, że problem ten nie omijał i mężczyzn. Mąż podejrzewający o niepłodność swoją żonę, mógł się z nią rozwieść i ponownie ożenić, licząc na potomstwo $\mathrm{z}$ nowego związku' ${ }^{1}$. Kobieta nie miała takiej możliwości, nawet jeśli uważała, że problem nie leży po jej stronie ${ }^{2}$. Również w późniejszych wiekach nie należało do rzadkości użycie bezpłodności jako pretekstu do oddalenia żony ${ }^{3}$.

Średniowieczne społeczeństwo miało jasno określone oczekiwania od zamężnych kobiet, szczególnie tych należących do wyższych warstw społecznych: miały zagwarantować ciągłość rodu, wydając na świat jak największą liczbę potomstwa, najlepiej płci męskiej ${ }^{4}$. Istotny wpływ na takie podejście miała wysoka śmiertelność dzieci, z których znaczny procent nie osiągał wieku dojrzałego ${ }^{5}$. Chcąc mieć pewność, że majątek pozostanie w rodzinie kobiety rodziły wielokrotnie ${ }^{6}$. Dziewczętom od wczesnych lat wpajano, że głównym obowiązkiem żony było rodzić jak najczęściej i z cierpliwością znosić ból porodów ${ }^{8}$.

${ }^{1}$ Por. A. Tatarkiewicz, Mater in statu nascendi. Społeczne i medyczne aspekty zdrowia reprodukcyjnego kobiet w starożytnym Rzymie, Poznań 2018, s. 66.

2 Por. tamże.

${ }^{3}$ Por. C. Opitz, La vita quotidiana delle donne nel tardo Medioevo (1250-1500), [w:] Ch. Klapisch-Zuber (red.), Storia delle donne. Il Medioevo, Roma-Bari 2005, s. 352-353.

${ }^{4}$ Agnolo Pandolfini (1360-1446), któremu przypisuje się dzieło Del governo della famiglia, zapisał słowa, którymi mąż zwrócił się do żony: „módlmy się do Boga [...] aby dał nam łaskę długiego wspólnego życia w radości i zgodzie i z wieloma synami”. Agnolo Pandolfini, Del governo della famiglia, Firenze 1847, s. 123. [Jeśli nie zaznaczono inaczej, tłumaczenia zostały wykonane przez autorkę artykułu]. Ponieważ nie było pewności, czy kandydatka na żonę urodzi w przyszłości potomstwo płci męskiej, Leon Battista Alberti (1404-1472) radził przyjrzeć się jej najbliższej rodzinie, ponieważ jeśli miała braci, należało przypuszczać, że również urodzi synów. Por. L.B. Alberti, Della famiglia, con prefazione di Carlo Capasso, Milano [b.d.], s. 130.

5 Więcej na ten temat por. A. Giallongo, Il bambino medievale. Storia di infanzie, Bari 2019, szczególnie s. 182-191.

6 Wiadomo na przykład, że we Florencji Pomina, żona Cabrina, w latach 14071421 urodziła piętnaścioro dzieci (w tym trzykrotnie bliźnięta). Por. Archivio Storico Lombardo. Giornale della Società Storica Lombarda e Bollettino della consulta archeologica del Museo Storico-Atristico di Milano, Milano 1877, s. 846-847.

7 Według Mikołaja z Gorran ( $\uparrow 1295)$ kobiety powinny rodzić przez cały czas aż do śmierci. Por. S. Vecchio, La buona moglie, [w:] G. Duby, M. Perrot, Storia delle donne in Occidente. Il Medioevo..., dz. cyt., s. 147.

${ }^{8}$ Por. F. Zambrini, C. Negroni (red.), Regole della vita matrimoniale di Frate Cherubino da Siena, Bologna 1888, s. 101. 
Duża liczba potomstwa była ponadto znacznym atutem, ponieważ dzięki ich aranżowanym małżeństwom wzmacniano i wzbogacano swoją familię. Takie podejście do małżeństwa, gdzie koncentrowano się głównie na profitach wynikających z jego zawarcia, już kilka wieków wcześniej krytykował grecki lekarz Soranos z Efezu (II w.): „wiele małżeństw pobiera się dla potomstwa, a nie dla czczej rozkoszy, przeto jest całkiem nieodpowiedniem, dowiadywanie się o sprawy dotyczące przodków i szukanie szlachetnego rodu i bogactwa, ale raczej badać trzeba, czy kobiety są w stanie zastąpić i czy są dobrze

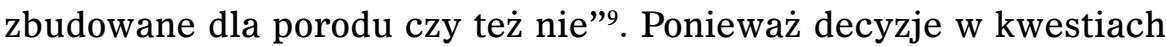
małżeństw zapadały wcześnie, nierzadko zanim przyszli małżonkowie wyszli $\mathrm{z}$ wieku niemowlęcego ${ }^{10}$, nie można było, jak sugerował Soranos, po budowie fizycznej stwierdzić o ich płodności. Pomimo że problem niepłodności uważano za istotny i znano różne choroby, które mogły mieć znaczny wpływ na prokreację kobiet, to jednak w epoce średniowiecza niewielu autorów podejmowało się napisania traktatów o tematyce stricte położniczo-ginekologicznej ${ }^{11}$.

W powstałych wówczas dziełach medycznych, kierowanych do lekarzy - mężczyzn, najczęściej tylko w kilku krótkich rozdziałach opisywano schorzenia dotykające kobiet oraz poruszano problematykę bezpłodności, poronień, ciąży i porodu ${ }^{12}$. Brak ośrodków kształcących położne ${ }^{13}$ sprawiał, że wiedza większości kobiet asystujących rodzącej

\footnotetext{
${ }^{9}$ Soranos, IX, 34.

${ }^{10}$ Por. E. Power, Donne del medioevo, M.M. Postan (red.), Milano 1999, s. 35.

11 Do takich autorów zaliczali się m.in. Orybazjusz (325-403), Aetiusz z Amidy (502-575), Paweł z Eginy (625-690), Mesue Starszy (750 r.), Rhazes (850-923) czy Avicenna (980-1037).

${ }^{12}$ Podaję tylko kilka przykładów. W Thesaurus pauperum Jana XXI znajdują się na przykład: De duritate et apostemate matricis, de provocatione mestruorum, de sistendis mensibus, de suffocatione matricis, de praecipitatione matricis, de vulvae constritione et de facili conceptu, de abortu, de difficili partu, de dolore post partum. Por. Petri Hispani Thesaurus pauperum, Francof. 1578. W Practica Brevis Jana Plateariusza jest kilka krótkich rozdziałów: De menstruis, de immoderato fluxu menstruorum, de suffucatione matricis, de impedimento conceptu. Por. G. Plateario, Practica Brevis. Un manuale di medicina practica del XII secolo, G. Lauriello (red.), Tuscania 2015; Guidonis de Gauliaco w Chirurgii poświęcił tej tematyce również kilka rozdziałów: De passionibus matricis, et primo de clausura, De amplificatione matricis, De tentigine matricis, De extractione fœtus, De extractione fecundinae, De mola matricis, De exitu matricis et longanonis. Por. Chirurgia magna Guidonis de Gauliaco, Lugduni 1585, s. 355-357.

${ }^{13}$ Całkiem inaczej prezentowała się kwestia związana $\mathrm{z}$ wykształceniem akuszerek (terminu akuszerka i położna używam zamiennie) w starożytnej Grecji, a później w Rzymie. Położne uczyły się zawodu w szkołach i stawiano im określone wymagania, o czym pisał grecki lekarz Soranos z Efezu, a później w VI w. Muscion. Por. Ginekologia Soranusa z Efezu. Przyczynek do historii ginekologii opracowany
} 
ograniczała się do ich własnego doświadczenia ${ }^{14}$. Powszechny analfabetyzm stanowił kolejną przeszkodę, ponieważ nawet jeśli istniały nieliczne dzieła o tematyce ginekologicznej, to rzadko która z kobiet potrafiła czytać i znała łacinę na tyle, aby móc skorzystać z zawartej w nich wiedzy. Jeszcze mniej kobiet potrafiło pisać, a te, które miały tę umiejętność, z reguły nie zajmowały się medycyną. Edukacja była wówczas dostępna tylko nielicznym, i nawet jeśli niektórym z kobiet udało się zdobyć wykształcenie medyczne, to z reguły koncentrowały się na wykonywaniu zawodu i nie rozpowszechniały wiedzy przez spisanie jej w formie traktatu. Ponadto znane są przypadki kobiet, których zainteresowania wykraczały poza położnictwo i kwestie ginekologiczne, o czym świadczą tytuły napisanych przez nie traktatów, których treść niestety nie zachowała się do czasów współczesnych $^{15}$. Wśród świeckich kobiet ${ }^{16}$ żyjących między VI a początkiem XVI w., które poruszały problematykę związaną ze schorzeniami o podłożu ginekologicznym, ciążą, porodem, opieką okołoporodową, higieną i kosmetyką można wymienić Metrodorę z Bizancjum ${ }^{17}$, Tro-

przez Dr Jana Lachsa w Krakowie, „Roczniki Towarzystwa Przyjaciół Nauk Poznańskiego”, v. XXVIII, Poznań 1902, s. 32-33; F. Ferrandini Troisi, La donna nella società ellenistica. Testimonianze epigrafiche, Bari 2000, s. 50. La „Gynaecia” di Muscione: manuale per le ostetriche e le mamme del VI sec. d. C., trad. it. R. Radicchi, Pisa 1970, s. 38. Więcej na temat zawodu położnych w starożytności i kwestii związanych z ciążą i porodem zobacz na przykład R. Forleo, P. Forleo, Cenni sulla storia dell'ostetricia e ginecologia, [w:] G.C. Di Renzo, Trattato di ginecologia e ostetricia, t. 1, Roma 2009; A. Tatarkiewicz, Żeby urodzić... rady lekarzy $i$ wsparcie bogów $w$ przygotowaniach do ciąży w czasach rzymskich, [w:] B. Płonka-Syroka, M. Dąsal (red.), Medycyna i religia, Warszawa 2017, s. 23-33; taż, Ciąża, poród i połóg pod opieka rzymskich bogów, [w:] K. Kochańczyk-Bonińska, L. Misiarczyk (red.), W kręgu religii śródziemnomorskich, Warszawa 2015, s. 57-70; taż, Mater in statu nascendi..., dz. cyt.

${ }^{14}$ Amerykańska badaczka Monika H. Green uważa, że z powodu niżu demograficznego i istniejących problemów politycznych zawód akuszerki znikł między VI/VII-XIII w. M.H. Green, Making Women's Medicine Masculine. The Rise of Male Authority in Pre-Modern Gynaecology, Oxford 2008, s. 34-36.

${ }_{15}$ Włoski badacz Salvatore de Renzi, który jako jeden z pierwszych zajął się badaniem historii szkoły medycznej w Salerno, podał imiona kilku kobiet żyjących między XIII-XV w., które napisały traktaty medyczne. Wymienia m.in. Abelę z Salerno, autorkę De atrabile i De natura seminis humani, Rebekę Guarna, autorkę De febribus, De urinis i De embrione oraz Mercuriade, która napisała De crisibus, De febris pestilenti, De curatione vulnerum i De unguentis. Por. S. De Renzi, Storia documentata della Scuola Medica di Salerno, Napoli 1857, s. 569.

${ }^{16}$ Świadomie pomijam tu działalność mniszek, takich jak na przykład Hildegarda z Bingen.

17 Więcej na temat Metrodory w j. angielskim por. K.C. Hurd-Mead, A History of Women in Medicine from the earliest Times to the beginning of the nineteenth century, Haddam 1938, s. 63, 73; w języku włoskim np. G. Del Guerra, La medicina bizantina e il codice medico-ginecologico di Metrodora (VI sec. d.C.), [w:] R. Radicchi, Introduzione 
tulę z Salerno ${ }^{18}$ i Katarzynę Sforzę ${ }^{19}$. Niniejszy artykuł, opierając się na średniowiecznym dziele Liber de sinthomatibus mulierum, omawia problematykę niepłodności kobiet i mężczyzn. Traktat ten, powstały przypuszczalnie w Salerno w czasie rozkwitu istniejącej tam szkoły medycznej, jest uważany za jedno z ważniejszych średniowiecznych dzieł o tematyce ginekologiczno-położniczej ${ }^{20}$. Zanim jednak zostanie omówiony problem płodności, uważa się za istotne poruszenie kwestii traktatu i jego twórcy.

\section{Autor i traktat Liber de sinthomatibus mulierum}

Postać autora Liber de sinthomatibus mulierum, który wraz z De curis mulierum i De ornatu mulierum ${ }^{21}$ tworzy corpus De passionibus mulierum $^{22}$, od dawna stanowi przedmiot badań wielu naukowców ${ }^{23}$.

e considerazioni sul "Gynaecia" di Muscione (VI sec. d. C) e studio dei suoi codici, Pisa 1968; A. M. Ieraci Bio, Testi ginecologici tra Oriente ed Occidente I, Metrodora ed il Dynameron di Nicola Mirepso II. Una testimonianza italo-greca su una Quaestio medicalis salernitana, [w:] La Scuola Medica Salernitana. Gli autori e i testi. Convegno Internazionale (Università degli Studi di Salerno, 3-5 novembre 2004); D. Jacquart, A. Paravicini Bagliani, Firenze 2007; E. Maderna, Medichesse. La vocazione femminile alla cura, Aboca 2014, s. 49-54; w języku polskim A. Głusiuk, Dbałość o urodę kobiet na podstawie traktatów Metrodory z Bizancjum i Trotuli z Salerno, „Seminare” 2018, nr 1, s. 145-154; taż, Ciąza, poród i powikłania po porodzie w traktacie „O chorobach kobiet” Metrodory $z$ Bizancjum, [w:] Medicina antiqua, mediaevalis et moderna. Historia - filozofia - religia, Kielce 2019, s. 121-134; taż, Choroby kobiet i sposoby ich leczenia na podstawie traktatu Metrodory z Bizancjum, „Medycyna Nowożytna” 2019, nr 25/1, s. 127-137.

${ }^{18}$ Literatura dotycząca Trotuli jest bardzo bogata, dlatego ograniczę się jedynie do kilku publikacji: F. Bertini, Trotula, il medico, [w:] B. Cardini, F. Cardini, Mt. Fumagalli, B. Brocchieri, C. Leopardi, Medioevo al femminile, Roma-Bari 2005, M.H. Green, Reconstructing the 'oeuvre' of Trota of Salerno, [w:] La Scuola Medica Salernitana..., dz. cyt., s. 183-233.

${ }^{19}$ Więcej na temat tej postaci i jej dzieła Experimenti de la Excelentissima Signora Caterina da Furlji w j. włoskim por. P.D. Pasolini, Caterina Sforza, vol. II, Roma 1893, s. 377; E. Maderna, dz. cyt., s. 127. W j. polskim por. K. Chłędowski, Rzym: Ludzie odrodzenia, Warszawa 1957, s. 166-169; A. Głusiuk, Experimenti de la Excelentissima Signora Caterina da Furlji. Katarzyna Sforza i jej sposoby na podkreślenie urody, „Saeculum Christianum" 2018, t. XXV, s. 172-183.

${ }^{20}$ Liczne kopie traktatu wskazują, że cieszył się on dużym zainteresowaniem w średniowieczu. Więcej na ten temat por. M.H. Green, Introduzione, [w:] taż (red.), Trotula. Un compendio medievale della medicina delle donne, Firenze 2009, s. 92-106.

${ }^{21}$ Liber de sinthomatibus porusza kwestie dotyczące dojrzewania dziewcząt, ciąży, porodu oraz schorzeń ginekologicznych. Drugi De curis mulierum opisuje zarówno problemy ginekologiczne, jak i porady kosmetyczne, natomiast trzeci De ornatu mulierum koncentruje się przede wszystkim na kwestiach związanych z higieną i kosmetyką.

${ }^{22} \mathrm{O}$ całym corpus pisze m.in. M.H. Green, Introduzione, [w:] taż (red.), Trotula. Un compendio..., dz. cyt., s. 39-82.

${ }^{23}$ Wśród zajmujących się tą postacią badaczy należy wymienić m.in. Monikę H. Green, autorkę wydania krytycznego traktatów przypisywanych Trotuli. Ta amerykańska ba- 
Początkowo autorstwo tych wszystkich traktatów przypisywano żyjącej w XI/XII w. Trotuli z Salerno. Podaje się jednak w wątpliwość, aby to ona była autorką trzech prac, zwłaszcza że tylko De curis mulierum łączono z jej imieniem ${ }^{24}$, a dwa pozostałe dzieła aż do XV w. cyrkulowały jako teksty anonimowe ${ }^{25}$.

Brakuje konkretnych informacji, które pozwoliłyby na jednoznaczną identyfikację autora traktatu. Nielicznych wskazówek dostarcza sam jego twórca, który w tekście podał kilka szczegółów, dzięki którym można założyć, że zdobył wykształcenie akademickie oraz że nie była mu obca medycyna ludowa. Na początku Liber de sinthomatibus mulierum autor wyjaśnia, dlaczego zdecydował się na napisanie traktatu o tematyce stricte ginekologiczno-położniczej. Głównym motywem miała być świadomość wstydu kobiet przed badaniem lekarskim „Et ipse condicione sue fragilitatis propter uerecundiam et faciei ruborem egritudinum suarum, que in secreciori loco accident, angustias non audent medico reuelare" ${ }^{26}$. Zastosowane słowo medicus, będące rodzaju męskiego, wskazuje jednoznacznie, że autor miał na myśli lekarzy tej płci. W kolejnym zdaniu pojawia się informacja o wpływie pewnej kobiety, dzięki której napisał traktat, który - jak sam zaznaczył - jest streszczeniem wielu ksiąg Hipokratesa i Galena ${ }^{27}$ : „Earum igitur miseranda calamitas et maxime cuiusdam mulieris gratia animum meum sollicitans et maxime cuiusdam mulieris gratia animum meum sollicitans inpluit, ut circa egritudines earum euidentius explanarem earum sanitati prouidendo" 28 . Niestety brakuje informacji na temat tajemniczej kobiety, o której autor pisze tylko w tym jednym miejscu. Postać ta wydaje się ważna, skoro o niej wspomniał, a tym samym warto się przy niej zatrzymać. Kobieta musiała cieszyć się szacunkiem autora, skoro przychylił się do jej prośby i napisał dzieło o rzad-

daczka napisała również kilka artykułów naukowych na temat Trotuli. Należy wspomnieć także np. Kate Campbell Hurd-Mead, Johna Bentona czy Pinę Cavallo Boggi.

${ }^{24} \mathrm{~W}$ artykule A. Głusiuk, Dbałość o urodę kobiet na podstawie traktatów Metrodory $z$ Bizancjum $i$ Trotuli $z$ Salerno została niewłaściwie podana informacja jakoby to De ornatu mulierum był łączony od samego początku z Trotulą. Traktat ten podobnie jak Liber de sinthomatibus cyrkulował jako anonimowy i jedynie De curis mulierum był od samego początku przypisywany lekarce z Salerno. Por. A. Głusiuk, Dbałość o urodę kobiet..., dz. cyt., s. 145-154.

${ }_{25}$ Por. M.H. Green, Introduzione, [w:] taż, Trotula. Un compendio medievale..., dz. cyt., s. 3.

${ }^{26}$ Liber de sinthomatibus mulierum 2, [w:] M.H. Green (red.) Trotula. Un compendio medievale..., dz. cyt.

${ }^{27}$ Tamże: „Ex libris ergo Ypocratis et Galyeni deo prestante pociora decerpere de[va]sudaui ut causas egritudinum earum et signa et curas exponerem et dicerem”.

${ }^{28}$ Por. tamże. 
ko wybieranej przez lekarzy tematyce. Można zatem wziąć pod uwagę dwie możliwości: pierwsza - kobieta pochodziła z wyższych warstw społecznych, na co wskazuje fakt, że mogła pozwolić sobie na skorzystanie z usług lekarza i miała śmiałość zasugerować napisanie traktatu. Wydaje się bowiem mało prawdopodobne, aby zwykła mieszczka, nawet jeśli korzystała z pomocy lekarskiej, miała tak duży wpływ na medyka, aby za jej namową zdecydował się na spisanie swojej wiedzy. Druga - nieznaną postacią była akuszerka, która wiedziała, że wstyd przed badaniem był częstą przyczyną rezygnacji z wizyty lekarskiej, co w konsekwencji doprowadzało do szukania pomocy u kobiet, których wiedza niejednokrotnie okazywała się niewystarczająca. Idąc za tym śladem, można przypuszczać, że traktat został napisany w celach edukacyjnych dla kobiet, które zajmowały się leczeniem i przyjmowaniem porodów. Struktura traktatu wydaje się potwierdzać hipotezę w kwestii podręcznika, ponieważ na początku w dokładny sposób opisano dane schorzenie lub anomalię, a następnie przedstawiono jedno lub kilka remediów mających pomóc w wyleczeniu. Trudno jednak w jednoznaczny sposób ustalić, czy faktycznie adresatkami tekstu były kobiety. Według amerykańskiej badaczki M.H. Green był on podobnie jak w przypadku innych dzieł, które powstały w ciągu kolejnych 400 lat $^{29}$ od powstania Liber de sinthomatibus mulierum, skierowany do lekarzy - mężczyzn. Wydaje się jednak, że Green nie wzięła pod uwagę traktatu włoskiego lekarza Michele’a Savonaroliego (1385-1468), który widząc braki w wykształceniu akuszerek, napisał właśnie dla nich traktat De regimine pregnantium et noviter natorum usque ad septemium ${ }^{30}$. Ponadto pojawia się kolejna wątpliwość, skoro w tekście zapisano, że kobiety nie ośmielały się mówić o swoich schorzeniach lekarzom - mężczyznom, to czy autor adresowałby właśnie do nich swój tekst? Nawet jeśli, jak zauważa Green, zdecydowana większość ówczesnych traktatów była skierowana do lekarzy mężczyzn nie można w sposób definitywny wykluczyć kobiet jako adresatek Liber de sinthomatibus mulierum ${ }^{31}$.

${ }^{29}$ Por. tamże, nota 3.

${ }^{30} \mathrm{M}$. Savonarola, Il trattato ginecologico-pediatrico in volgare. Ad mulieres ferrarienses de regimine pregnantium et noviter natorum usque ad septennium, L. Belloni (red.), Milano 1952, s. 3-4.

${ }^{31}$ Według Salvatore’a de Renzi traktat powstał na terenie Salerno, na co wskazuje użyte w tekście słownictwo. Zważywszy, że w mieście istniała jedna z ważniejszych szkół medycznych średniowiecznej Europy, jest prawdopodobne, aby Liber de sinthomatibus był podręcznikiem skierowanym do studiujących tam studentów. Gdy weźmie się pod uwagę wydane przez Fryderyka II prawo dające kobietom możliwość podjęcia nauki, nie można wykluczyć ich jako potencjalnych adresatek traktatu. Zdaniem De 
Kwestia płci autora tekstu również nie jest do końca jasna ${ }^{32}$. Zastanawiające są użyte w traktacie słowa skierowane do akuszerek, które miały pouczać obecnego przy porodzie lekarza - mężczyznę, aby nie spoglądał w twarz rodzącej, by nie wzbudzać u niej wstydu i ograniczyć jej skrępowanie ${ }^{33}$. Czy lekarz - mężczyzna przejmowałby się takim szczegółem, jak komfort psychiczny rodzącej? Jest to oczywiście możliwe, ale bardziej prawdopodobne wydaje się, że zwróciłaby na to swoją uwagę kobieta, zwłaszcza jeśli znała taką sytuację z własnego doświadczenia.

W tym miejscu warto również dodać, że Liber de sinthomatibus mulierum zdecydowanie różni się od pozostałych dwóch traktatów ${ }^{34}$.

Renzi, który analizował wiele dokumentów, które to niestety uległy zniszczeniu podczas II wojny światowej, w Salerno kobiety leczyły kobiety, a ich obecność w szkole jako nauczycielek i studentek była czymś normalnym. Por. Collectio Salernitana, ossia Documenti inediti, e trattati di medicina appartenenti alla scuola medica salernitana, raccolti ed illustrati da G.E.T. Henschel, C. Daremberg, S. De Renzi: premessa la storia della scuola, e pubblicati a cura di Salvatore De Renzi, vol I, Napoli 1852, s. $152-153$.

32 Według amerykańskiego badacza Johna F. Bentona wszystkie trzy traktaty tworzące corpus zostały napisane przez mężczyzn. Więcej por. J.F. Benton, Trotula, Women's Problems, and the Professionalization of Medicine in the Middle Ages, „Bulletin of the History of Medicine”, nr 59, 1 (Spring 1985), s. 46.

33 „Et qui assistunt non respiciant eam in uultu, quia inde mulieres solent uerecundari in partu et post partum". Liber de sinthomatibus mulierum 92. Jak zauważa Green, słowo „qui” nie wskazuje jednoznacznie, kogo autor miał na myśli. Mogło to dotyczyć lekarzy, a zatem tłumaczenie byłoby „ci lekarze”, lub osób - „te osoby”, jeśli wśród mężczyzn były obecne również kobiety. Por. tamże, s. 169, n. 48.

${ }^{34}$ Uwagę zwraca również użycie form czasowników. W Liber de sinthomatibus mulierum oraz w De ornatu mulierum stosowano często tryb rozkazujący ,accipe” (Liber de sinthomatibus mulierum 17, 19, 21, 22, 24, 25, 40, 43, 48, 54, 61, 62, 63, 64, 68, 69, 72, 74, 81, 82, 101, 112, 113, 125, 130, 131; De ornatu mulierum 242, 243, 244, 246, 250, 251, 252, 263, 268, 272, 274, 279, 282, 288, 290, 291, 296, 302, 304, 305, 309); „recepe” (Liber de sinthomatibus mulierum 22, 86; De ornatu mulierum 245, 247, 248, 254, 259, 260, 264, 266, 270, 273, 276, 278, 281, 286, 287, 288, 290, 307, 308, 310); „fac” (Liber de sinthomatibus mulierum 43; De ornatu mulierum 257, 265, 282, 286, 288) lub druga osobę liczby pojedynczej, jak „poteris”, „,intromittas” czy „,scias”. W De curis mulierum oprócz słów w trybie rozkazującym (m.in. ,accipe” 135, 136, 140, 141, 148, 159, 164, 173, 174,175, 177, 190, 191, 192, 194, 204, 206, 210, 211, 213, 214, 215, 216, 218, 219, 220, 221, 222, 223, 225, 226, 227, 228, 229, 230, 231, 232, 233, 234, 235, 236, 238; „recipe” 134, 138, 166, 172, 173, 212, 227, 236, 237, 239; „fac” 136, 140, 208, 214, 216, 221, 231) większość czasowników występuje głównie w pierwszej osobie liczby mnogiej. Do najczęściej pojawiających się należą: „subuenimus” 136, 139, 142, 146, 147, 149, 150, 155, 188, 204; „facimus” 134, 142, 157, 158, 163, 175, 187, 189, 201, 205; „faciamus” 142, 145, 147, 157, 161, 172, 200; ,inponimus” 142, 149, 150, 156, 161, 166, 167, 172, 189; „apponimus” 154, 155, 180, 187, 188, 199, 207; , distemperamus” 153, 161, 171, 174, 200, 204, 207. Na uwagę zasługuje fakt, że czasowniki w pierwszej osobie liczby mnogiej występują do miejsca Ad formicationes et syrones, a od De dolore oculorum do końca traktatu czasownik w wymienionej formie (uidebimus) pojawia się tylko jeden raz. Ta 
W pierwszej kolejności zauważa się liczne odwołania do autorów, takich jak Hipokrates ${ }^{35}$, Dioskurydes ${ }^{36}$, Galen ${ }^{37}$, Rufus ${ }^{38}$, Orybazjusz ${ }^{39}$ czy Paweł z Eginy ${ }^{40}$, których brak w De curis mulierum i w De ornatu mulierum. Tak liczne odniesienia do wcześniejszych lekarzy świadczą o bardzo dobrej znajomości literatury przedmiotu ${ }^{41}$, co pozwala sądzić, że jego autor miał wiedzę akademicką, którą zdobył na jednym $\mathrm{z}$ istniejących wówczas wydziałów medycznych. Jego wykształcenie wydają się również potwierdzać słowa, kiedy mówi o stosowanych przez akuszerki środkach ${ }^{42}$. Zarówno wspomnienie o położnych, jak i o ich metodach, które jak zaznaczył były „nobis obscura”- nam nieznane - sugerują, że autorem traktatu był lekarz. Ponadto jak wynika z tekstu, nie była mu obca medycyna ludowa oraz znajomość zaklęć przyśpieszających poród ${ }^{43}$. Niestety brak innych wskazówek uniemożliwia jednoznaczne określenie, kim był autor traktatu i tym samym sprawia, że kwestia ta pozostaje nadal otwarta.

\section{Problemy z płodnością kobiet i sposoby na zajście w ciążę}

Ówcześni medycy byli świadomi istnienia różnych przeszkód uniemożliwiających kobietom posiadanie potomstwa. Bezdzietność mogła być spowodowana nieprawidłową budową fizyczną ${ }^{44}$, anomaliami narządów rodnych, brakiem oczyszczenia miesięcznego ${ }^{45}$ lub scho-

nieoczekiwana zmiana stylu może sugerować, że traktat został napisany nie przez jedną, lecz przez dwie osoby.

${ }_{35}$ Por. Liber de sinthomatibus mulierum 2, 73, 88, 114.

36 Por. tamże 57.

37 Por. tamże 2, 6, 13, 46, 66, 67, 73, 83, 88.

${ }^{38}$ Por. tamże 6.

${ }^{39}$ Por. tamże 50.

40 Por. tamże 68.

${ }^{41}$ W De curus mulierum pojawiają się jedynie imiona dwóch lekarzy łączonych z Salerno Cofon oraz magister Ferrarius. W De ornatu mulierum nie wymieniono natomiast żadnego lekarza.

${ }^{42}$ Liber de sinthomatibus mulierum 118: „Item notandum est quod sunt quedam phisicalia remedia quorum uirtus est nobis obscura, que ab obstetricibus facta profuerunt".

${ }^{43} \mathrm{~W}$ rozdziale poświęconym trudnościom, które mogą pojawić się podczas porodu, autor pisze na przykład: „Vel scribantur hec nomina in caseo uel butyro: + sa. e. op. ab. z. po. c. zy. e. pe. pu. c. ac. Sator arepo tenet os pera rotas, et dentur ad manducandum”. Tamże 98.

${ }^{44}$ Według autora nasienie nie mogło dostać się do macicy, jeśli kobieta była zbyt mizerna i chuda lub przeciwnie - zbyt gruba. Przeszkodą w poczęciu dziecka była również śliska i miękka macica, w której nasienie nie mogło się utrzymać. Por. tamże 129.

${ }^{45}$ Por. Soranos VI, 28. 
rzeniami, takimi jak owrzodzenia, o których pisał Hipokrates ${ }^{46}$, czy ropienia, o których wspominał Soranos ${ }^{47}$. Zdarzały się również przypadki, że kobiety nie zachodziły w ciążę, pomimo że wcześniej rodziły. Brak kolejnego potomstwa mógł być następstwem komplikacji, które pojawiły się podczas ostatniego rozwiązania lub wyniszczenia organizmu w wyniku zbyt licznych ciąż i porodów. O niekorzystnym wpływie ciąży na zdrowie kobiet pisał już Soranos ${ }^{48}$, a autor omawianego traktatu uważał, że jeśli są częste, przyczyniają się do chorób, szczególnie tych dotykających narządów rodnych ${ }^{49}$.

W Liber de sinthomatibus mulierum problem związany z zajściem w ciążę autor łączy z menstruacją pojawiającą się u dziewcząt około trzynastego roku życia ${ }^{50}$ i powszechnie wówczas nazywaną flores ${ }^{51}$ kwiaty, kwiatki. Brak comiesięcznego oczyszczenia oraz wszelka jego nieregularność zdaniem autora utrudniała poczęcie, o czym świadczą liczne wskazówki informujące, jak należało postąpić w przypadku braku $^{52}$, zbyt skąpej ${ }^{53}$ lub zbyt obfitej menstruacji ${ }^{54}$.

Ponieważ niepłodność dotykała także mężczyzn, autor traktatu, chcąc ustalić, po czyjej stronie znajduje się problem i czy można mu zaradzić, zalecał przeprowadzić następujące doświadczenie: „weź dwa naczynia i do każdego z nich wsyp otręby, do jednego z nich dodaj trochę moczu mężczyzny, a do drugiego moczu kobiety i pozostaw na dziewięć lub dziesięć dni. Jeśli defekt jest po stronie kobiety w jej pojemniku znajdziesz wiele robaków i otręby będą wydawały brzydki zapach. To samo znajdziesz $\mathrm{w}$ drugim naczyniu, jeśli defekt jest po stronie mężczyzny"55. W przypadkach, kiedy po przeprowadzeniu tego badania w żadnym z dwóch naczyń nie zaobserwowano opisane-

${ }^{46}$ Por. Ippocrate, Natura della donna, V. Andò (red.), Milano 2008, cap. 6, 7, 14, 21.

${ }^{47}$ Por. Soranos VI, 28.

${ }^{48}$ Por. tamże XI, 42.

${ }^{49}$ Liber de sinthomatibus mulierum 2: „Quoniam ergo mulieres uiris sunt debilitores natura, ut quia in partu sepissime molestantur, hinc est quare in eis sepius habundant egritudines, et maxime circa membra operi nature debita".

50 Por. Liber de sinthomatibus mulierum 3.

51 Por. tamże.

52 Por. tamże 8-18.

53 Por. tamże 19-28.

${ }^{54}$ Por. tamże 29-44.

55 Tamże 74: „Accipe duas ollas et in utraque pone cantabrum, et de urina uiri pone in una earum cum cantabro, et in alia de urina mulieris, et olle dimittantur per .ix. uel dies .x. Et si sterilitas sit uicio mulieris, inuenies uermes multos in olla sua et cantabrum fetidum. Similiter in alia si sit uicio uiri”. Podobny sposób na zdiagnozowanie problemu znajduje się w De secretis mulierum Pseudo-Alberta Wielkiego. Por. Albertus Magnus, De secretis mulierum, Amstelodami 1662, cap. XII. 
go zjawiska, wówczas należało przyjąć, że oboje są płodni i można im pomóc, stosując odpowiednie środki ${ }^{56}$.

Niepłodność kobiet mogła być spowodowana zbyt dużą ciepłotą macicy lub jej nadmierną wilgocią ${ }^{57}$. W przypadku nadmiernej ciepłoty i suchości macicy wiele zależało od wieku kobiety, ponieważ jeśli ukończyła trzydziesty rok życia, należało uznać jej przypadek za nieuleczalny ${ }^{58}$, natomiast jeśli była młodsza, można jej było pomóc w następujący sposób: „weź prawoślaz i bylicę i ugotuj je w wodzie, i tym wywarem wykonaj pacjentce fumigacje trzy lub czterokrotnie. Pomiędzy jedną, a drugą fumigacją przygotuj czopki oraz pessaria domaciczne z oleju piżmowego i z samego piżma, tak, aby wzmocnić macicę. Siódmego dnia, po oczyszczeniu lub po wykonanej fumigacji, weź trifera magna ${ }^{59}$ wielkości żołędzia, owiń ją bawełną i z tego przygotuj czopek domaciczny" ${ }^{60}$. Następnie kobieta miała połączyć się z mężem, a jeśli uznano za konieczne, kurację należało powtórzyć w kolejnym tygodniu ${ }^{61}$.

Innym czynnikiem utrudniającym poczęcie była zbyt duża wilgoć macicy, której objawem było ciągłe łzawienie oczu ${ }^{62}$. W takich przypadkach w pierwszej kolejności należało oczyścić narząd przy pomocy Theodoricon euporiston, a następnie przygotować pessarium wykonane z piżma i medykamentu o nazwie trifera. Leczenie wymagało czasu, i dopiero kiedy zauważano zanik nadmiaru wilgoci, można było założyć pessarium wykonane z piżma i olejku lub z innej aromatycznej substancji ${ }^{63}$. 0 prawidłowym oczyszczeniu autor pisał ,,jeśli będzie dobrze oczyszczona odczuje zapach [piżma] w ustach, i jeśli ktoś ją

${ }^{56}$ Por. Liber de sinthomatibus 74.

57 Por. tamże 129.

58 Por. tamże.

59 Środek leczniczy składający się z wielu składników, wśród których znajdowało się również opium.

${ }^{60}$ Tamże: „Si iuuencula sit et passio diuturna non sit, subuenias sic: accipe maluam, arthimesiam, et in aqua decoque, et cum tali decoctione ter uel quater fumiges patientem. Inter has fumigationes suppositoria et etiam pessaria uulue cum oleo musceleo et modico musco facies, ut matrix confortetur. Sed in die septimo post purgationem uel fumigationem factam, accipe de trifera magna ad modum glandis et similiter inuolue in bombace, et inde suppositorium facies uulue, ut tot fumigationibus matrix recipiat aliquam confortationem, lenitatem et lanuginem".

${ }^{61}$ Tamże: „In sequenti uero die eam facies cum uiro coire, eadem autem cura sequenti septimana si expediat utaris faciendo fumigationes predictas et cetera ut diximus beneficia adhibendo".

${ }^{62}$ Według autora nerwy łączyły macicę z mózgiem. Kiedy było w niej zbyt dużo wilgoci, płyn przedostawał się do mózgu, a następnie schodził do oczu, prowokując ciągłe łzawienie. Por. tamże.

${ }^{63}$ Por. tamże 130. 
pocałuje będzie myślał, że miała piżmo w ustach. Tak samo, jeśli z powodu oczyszczenia będzie odczuwać pragnienie, będziesz wiedział, że jest dobrze oczyszczona. Po tym niech często łączy się [z mężem], tak, aby poczęła" ${ }^{4}$. Skuteczny w poczęciu miał być również okład z wełny namoczonej w mleku oślicy, położony na pępku i pozostawiony dopóki kobieta nie połączyła się z mężem ${ }^{65}$.

Spośród znanych w średniowieczu afrodyzjaków stosowanych przez kobiety w traktacie można znaleźć głównie te pochodzenia zwierzęcego, takie jak jądra niewykastrowanego wieprza lub dzika ${ }^{66}$, sproszkowana wątroba i jądra prosięcia ${ }^{67}$, jądra zająca ${ }^{68}$.

\section{Niepłodność u mężczyzn}

Pomimo że o niepłodność z reguły podejrzewano kobiety, to jednak wiedziano, że dotyczy ona obu płci. W Liber de sinthomatibus mulierum znajdują się głównie krótkie adnotacje na temat niepłodności mężczyzn zapisane przy okazji omawianej szerzej problematyki kobiet. Dopiero na końcu traktatu autor poświęcił więcej uwagi kwestii niepłodności mężczyzn, ograniczając się jednak zaledwie do kilku zdań.

Według autora przyczyna męskiej niepłodności mogła być natury fizycznej - zbyt płynne nasienie lub psychologicznej „ex defectu spiritus"69, do której zaliczono impotencję znaną już w poprzednich

${ }^{64}$ Tamże: „Et si bene purgata fuerit, sentiet odorem in ore, et si quis eam osculatus esset, crederet eam muscum in ore tenere. Item si sitim propter hanc purgationem habuit, scias eam bene purgatam esse, et ita purgata frequenter coeat ut concipiat".

${ }_{65}$ Tamże 78: „Accipiat mulier lanam succidam intinctam in lacte asine et liget eam super umbelicum et si tibi donec concumbat”. Por. Albertus Magnus, De secretis mulierum, cap. XII.

${ }^{66}$ Tamże 82: „Si mulier uult impregnari, accipe testículos uerris uel apri et sicca et fiat puluis, et bibat cum uino post purgationem menstruorum. Deinde coeat cum uiro et concipiet”. Stosowanie części ciał zwierząt uznawanych za silne i pełne wigoru jako środków wspomagających pożądanie nie było niczym nowym. Już we wcześniejszych wiekach pisał o nich m.in. Pliniusz.

${ }^{67}$ Tamże 77, „Accipiat mulier epar et testiculis parui porci quem solum scropha ediderit, et desiccentur, et in puluerem reducantur, et detur in potu masculo qui non potest generare et hic generabit, uel mulieri et hec concipiet". Podobna receptura znajduje się w De secretis mulierum. Por. Albertus Magnus, De secretis mulierum, cap. XII.

${ }^{68}$ Tamże 76: „Si uult masculum concipere, uir eius accipiat matricem et uuluam leporis et faciat desiccare, et puluerum distemperat cum uino et bibat. Similiter et mulier faciat de testiculis leporiis, et in fine menstruorum iacet cum uiro suo et tunc masculum concipiet”. Podobne zalecenie, ale dotyczące jedynie kobiety znajduje się w De secretis mulierum. Por. Albertus Magnus, De secretis mulierum, cap. XII.

${ }^{69}$ Por. tamże 131. 
wiekach ${ }^{70}$. W pierwszym przypadku można było pomóc, wzbogacając dietę m.in. o cebulę i pasternak ${ }^{71}$, a w drugim - autor radził skorzystać z bogatej gamy afrodyzjaków. Do wymienionych w traktacie „wspomagaczy" stosowanych przez mężczyzn należy zaliczyć wspomnianą wcześniej wątrobę i jądra prosięcia ${ }^{72}$ oraz macicę i pochwę zająca, które po sproszkowaniu dodawano do $\mathrm{wina}^{73}$. Za równie skuteczny uważano medykament - arrogon, którym nacierano lędźwie lub, jak radził autor, „niech [mężczyzna] weźmie nasiona rukoli i wilczomlecza i niech je rozdrobni na drobny proszek, i niech doda go do olejku $\mathrm{z}$ mchu i z mięty polej i niech nasmaruje tym nerki" ${ }^{\text {" }}$.

\section{Podsumowanie}

W średniowieczu, podobnie jak w poprzednich wiekach, uważano, że głównym celem małżeństwa było posiadanie legalnego potomstwa. Niepłodność stanowiła istotny problem, o który z reguły podejrzewano kobiety. Liber de sinthomatibus mulierum jest jednym z nielicznych średniowiecznych traktatów medycznych, w którym więcej uwagi poświęca się niepłodności. Pomimo że autor poruszył kwestie prokreacji obu płci, to jednak zdecydowanie więcej uwagi poświęcił kobietom, co wskazuje, że to głównie je obarczał odpowiedzialnością za brak potomstwa. Opisane w traktacie remedia mające pomóc $\mathrm{w}$ wydaniu na świat upragnionego potomka ukazują wiedzę ówczesnych lekarzy w tej kwestii. Już wówczas wiedziano, że nieuregulowana menstruacja, nieprawidłowa budowa narządów rodnych czy kłopoty natury psychologicznej mogą mieć negatywny wpływ na prokreację.

\section{Bibliografia}

\section{Źródła}

Alberti L.B., Della famiglia, con prefazione di Carlo Capasso, Milano [b.d.].

Albertus Magnus, De secretis mulierum, Amstelodami 1662.

Agnolo Pandolfini, Del governo della famiglia, Firenze 1847.

${ }^{70}$ Por. A. Tatarkiewicz, Mater in statu nascendi..., dz. cyt., s. 76.

${ }^{71}$ Tamże: „Hiis subuenimus cum augmentantibus et generantibus sperma, ut sunt cepe, pastinace domestice, et similia”.

72 Por. tamże 77.

73 Por. tamże 76.

${ }^{74}$ Liber de sinthomatibus 131. 
Archivio Storico Lombardo. Giornale della Società Storica Lombarda e Bollettino della consulta archeologica del Museo Storico-Atristico di Milano, Milano 1877.

Chirurgia magna Guidonis de Gauliaco, Lugduni 1585.

Ginekologia Soranusa z Efezu. Przyczynek do historii ginekologii opracowany przez Dr Jana Lachsa w Krakowie, „Roczniki Towarzystwa Przyjaciół Nauk Poznańskiego”, v. XXVIII, Poznań 1902.

Giovanni Plateario, Practica Brevis. Un manuale di medicina practica del XII secolo, G. Lauriello (red.), Tuscania 2015.

Ippocrate, Natura della donna, V. Andò (red.), Milano 2008.

La „Gynaecia” di Muscione: manuale per le ostetriche e le mamme del VI sec. d. C., trad. it. Radicchi R., Pisa 1970.

Liber de sinthomatibus mulierum, [w:] M.H.Green (red.), Trotula. Un compendio medievale della medicina delle donne, Firenze 2009.

Michele Savonarola, Il trattato ginecologico-pediatrico in volgare. Ad mulieres ferrarienses de regimine pregnantium et noviter natorum usque ad septennium, L. Belloni (red.), Milano 1952.

Petri Hispani Thesaurus pauperum, Francof. 1578.

Zambrini F., Negroni (red.) C., Regole della vita matrimoniale di Frate Cherubino da Siena, Bologna 1888.

\section{Opracowania}

Benton J.F., Trotula, Women's Problems, and the Professionalization of Medicine in the Middle Ages, „Bulletin of the History of Medicine", nr 59, 1(Spring 1985).

Bertini F., Trotula, il medico, [w:] Cardini B., Cardini F., Fumagalli Mt., Brocchieri B., Leopardi C., Medioevo al femminile, Roma-Bari 2005.

Collectio Salernitana, ossia Documenti inediti, e trattati di medicina appartenenti alla scuola medica salernitana, raccolti ed illustrati da Henschel G.E.T., Daremberg C., De Renzi e S.: premessa la storia della scuola, e pubblicati a cura di Salvatore De Renzi, vol I, Napoli 1852.

De Renzi S., Storia documentata della Scuola Medica di Salerno, Napoli 1857.

Del Guerra G., La medicina bizantina e il codice medico-ginecologico di Metrodora (VI sec. d.C.), [w:] Radicchi R., Introduzione e considerazioni sul "Gynaecia" di Muscione (VI sec. d. C) e studio dei suoi codici, Pisa 1968.

Ferrandini Troisi F., La donna nella società ellenistica. Testimonianze epigrafiche, Bari 2000. 
Forleo R., Forleo P., Cenni sulla storia dell'ostetricia e ginecologia, [w:] Di Renzo G.C., Trattato di ginecologia e ostetricia, t. 1, Roma 2009.

Giallongo A., Il bambino medievale. Storia di infanzie, Bari 2019.

Głusiuk A., Choroby kobiet i sposoby ich leczenia na podstawie traktatu Metrodory z Bizancjum, „Medycyna Nowożytna” 2019, nr 25/1.

Głusiuk A., Ciqża, poród i powikłania po porodzie w traktacie „O chorobach kobiet" Metrodory z Bizancjum, [w:] Medicina antiqua, mediaevalis et moderna. Historia - filozofia - religia, Kielce 2019.

Głusiuk A., Dbałość o urodę kobiet na podstawie traktatów Metrodory $z$ Bizancjum i Trotuli z Salerno, „Seminare” 2018, nr 1.

Głusiuk A., Experimenti de la Excelentissima Signora Caterina da Furlji. Katarzyna Sforza i jej sposoby na podkreślenie urody, „Saeculum Christianum" 2018, nr XXV.

Green M.H., Reconstructing the 'oeuvre' of Trota of Salerno, [w:] La Scuola Medica Salernitana. Gli autori e i testi. Convegno Internazionale (Università degli Studi di Salerno, 3-5 novembre 2004), Jacquart D., Paravicini Bagliani A., Firenze 2007.

Green M.H., Making Women's Medicine Masculine. The Rise of Male Authority in Pre-Modern Gynaecology, Oxford 2008.

Hurd-Mead K.C., A History of Women in Medicine from the earliest Times to the beginning of the nineteenth century, Haddam 1938.

Ieraci Bio A.M., Testi ginecologici tra Oriente ed Occidente I, Metrodora ed il Dynameron di Nicola Mirepso II. Una testimonianza italo-greca su una Quaestio medicalis salernitana, [w:] La Scuola Medica Salernitana. Gli autori e i testi. Convegno Internazionale (Università degli Studi di Salerno, 3-5 novembre 2004), Jacquart D., Paravicini Bagliani A., Firenze 2007.

Maderna E., Medichesse. La vocazione femminile alla cura, Aboca 2014. Opitz C., La vita quotidiana delle donne nel tardo Medioevo (12501500), [w:] Ch. Klapisch-Zuber (red.), Storia delle donne. Il Medioevo, Roma-Bari 2005.

Pasolini P.D., Caterina Sforza, vol. II, Roma 1893.

Power E., Donne del medioevo, M.M. Postan (red.), Milano 1999.

Tatarkiewicz A., Ciqża, poród i połóg pod opieka rzymskich bogów, [w:] K. Kochańczyk-Bonińska, Misiarczyk L. (red.), W kręgu religii śródziemnomorskich, Warszawa 2015.

Tatarkiewicz A., Mater in statu nascendi. Społeczne i medyczne aspekty zdrowia reprodukcyjnego kobiet $w$ starożytnym Rzymie, Poznań 2018. 
Tatarkiewicz A., Żeby urodzić... rady lekarzy i wsparcie bogów w przygotowaniach do ciaży w czasach rzymskich, [w:] B. Płonka-Syroka, M. Dąsal (red.), Medycyna i religia, Warszawa 2017.

Vecchio S., La buona moglie, [w:] G. Duby, M. Perrot, Storia delle donne in Occidente. Il medioevo, Ch. Klapisch-Zuber (red.), Roma-Bari 2005. 